\title{
Vagotonicity of Violence: Biochemical and Cardiac Responses to Violent Films and Television Programmes
}

\author{
MALCOLM CARRUTHERS, PETER TAGGART
}

British Medical fournal, 1973, 3, 384-389

\section{Summary}

In a search for a reproducible means of evoking different types of emotional stress it was found that in spite of increased adrenaline secretion slowing of the heart occurred when watching violent television programmes. Further evidence of increased vagal tone was provided by the "sinus arrhythmia" effect, a widening of the gap between the maximum and minimum heart rates during the respiratory cycle in parts of the humour, violence, and suspense sections of the television programme.

Groups of people taken to see two particularly violent films showed similar evidence suggesting vagal overactivity, together with increases in plasma free fatty acids and decreases in triglycerides. As these changes occurred even with $\beta$-blockade it is suggested that they might be caused by non-sympathetically mediated changes in the levels of hormones, such as growth hormone, producing lipolysis.

The ability to assess objectively an individual's reaction to viewing violence might make it possible to judge the likely social impact of violent films and television programmes.

\section{Introduction}

Biochemical and cardiological responses to stress are regulated by the net balance between sympathetic and parasympathetic activity. The interaction of these two systems, usually acting in opposition to each other, was recognized at the beginning of this century by physiologists such as Cannon. In his monograph Bodily Changes in Pain, Hunger, Fear and Rage (Cannon, 1929) he quoted the inhibition of intestinal mobility and secretions by sympathetic overactivity induced by fear and their increase by parasympathetic activity induced by hunger and the emotion of aversion. He recorded two interesting examples of vagal action. Firstly, of a woman who witnessed the slaughter of a pig and on being reminded of the similarity between the pig's entrails and her own was so repulsed by the idea that she vomited intermittently for several months. The second was of soldiers suffering vagal inhibition of the heart on witnessing extreme violence in warfare. Such vasovagal attacks are common in medical students and nurses attending their first operating sessions. They are also experienced by patients undergoing endoscopic procedures (Rollason, 1964). In one such episode experienced by a patient undergoing cardiac catheterization not only was there evidence of considerable vagal overactivity, in that syncope occurred and the pulse rate slowed to 30 beats/ min, but plasma noradrenaline levels decreased from $1.00 \mu \mathrm{g} / 1$.

Institute of Ophthalmology, London W.C.1

MALCOLM CARRUTHERS, M.D., M.R.C.PATH., Senior Lecturer in Chemical Pathology (Present address: Department of Chemical Pathology (Research), St. Mary's Hospital Medical School, London W2 IPG)

Middlesex Hospital, London W.1

PETER TAGGART, M.R.C.P., Lecturer in Medicine before the event to $0.20 \mu \mathrm{g} / \mathrm{l}$. during it, adrenaline remaining at $0.01 \mu \mathrm{g} / 1$. Similar brief reductions in plasma noradrenaline have been noted in people fainting during venepuncture and dentistry.

There is currently much concern about the effects of exposing people to violence on television and in films. This concern is repeatedly expressed in the medical and the lay Press (Lancet, 1970; British Medical fournal, 1973). Commenting on the large increase in crimes of violence in England and Wales during 1972, both the Chief Inspector of Constabulary and the Commissioner of the Metropolitan Police suggested in their recent annual reports (The Times, 14 June) that perhaps the blame lay with television, the cinema, and other mass media, particularly in influencing young people. The B.B.C. has set up an advisory group on the social effects of television, which is paying special attention to the portrayal of violence as shown on television and in films. Attempts to assess these effects on a subjective basis, as in the B.B.C. Audience Research Department report Violence on Television (1972), have not provided any clear-cut conclusions. It was therefore decided to examine the objective measures provided by biochemical and E.C.G. changes resulting from such exposure.

\section{Television Watching}

\section{METHOD}

Ten pairs of healthy men and women watched a prerecorded television programme, two couples at a time. The subjects fasted for six hours after a light lunch and, separately in a side room, had a Branula size $0,1 \frac{1}{2}$-in $(3 \cdot 8-\mathrm{cm})$ catheter inserted into an antecubital vein. Patency was maintained with $3.8 \%$ sodium citrate introduced via a tap which could also be used for withdrawing the blood samples. E.C.G. electrodes were attached in the V6 position and connected to a central switching box outside the viewing room by extended leads. The E.C.G. of each subject in turn could be recorded on a Devices cardiograph by rotating the selection switch.

The hour-long test programme was supplied by the Further Education Department of the B.B.C. and the study formed part of a programme being made by that department on the social and biological effects of stress. The telerecording was replayed on a conventional domestic receiver situated in the comfortable, congenial setting of the television viewing room of Moorfields Hospital, High Holborn, from an Ampex 7003 telerecorder unit in an adjacent control room. The subjects' reactions to the programme could be observed through a glass panel between these two rooms. The viewing room was illuminated by subdued overhead lighting.

The four sections of the programme lasted about 15 minutes each and represented the following conditions.

Relaxation.-This control period consisted of a soporific commentary on underwater life, including various types of seaweed and small marine animals.

Humour.-To cover a range of comedy two seven-minute extracts were combined in this section. The first was from a Morecambe and Wise television programme which won a Golden Rose of Montreux award. It consisted mainly of dialogues between the two comedians. The second featured Eric Sykes in a situation comedy describing an attack on the B.B.C. Television Centre by Red Indians. The aggressive element of 
humour was evident in the castration threats in the former and ritual mayhem in the latter.

Violence.-Verbal assault followed by physical assault on a bus conductor by a gang of teenagers. The "beating-up" was brief and not explicit by present-day standards.

Suspense.-A very tense situation from the last of a series of Doomwatch programmes in which one of the heroes is defusing an activated hydrogen bomb washed up on to the end of a pier. After an agonizing and eventful countdown the last charge explodes and kills him.

Though it might have been preferable to vary the running order, because of difficulty in altering the videotape the sections were always shown in the sequence given, with five-minute intervals in between to allow for the collection of blood samples via the cannulae. This and the subsequent injection of citrate was carried out with as little disturbance as possible and the arm re-enclosed in a paper towel to minimize the impairment of concentration on the programme inherent in this type of experi- ment. Biochemical estimations were performed as described previously (Taggart and Carruthers, 1971).

\section{Results}

It was difficult to distinguish any consistent biochemical response to the different sections of the television programme (table I). The only change in plasma catecholamines which reached even the $5 \%$ level of significance was a rise in adrenaline occurring after the humorous section. Overall the free fatty acids rose and triglycerides and cholesterol fell during the programme. Glucose levels rose after the violence section and remained high during the suspense and second control period.

The most obvious change in the E.C.G. recordings was a moderate bradycardia starting during the humorous section of the programme and continuing during the violence and suspense sequence. In view of the presence of increased sympathetic

TABLE I-Plasma Catecholamine, Lipid, and Glucose Levels after Each Period of Television Programme

\begin{tabular}{|c|c|c|c|c|c|c|c|c|c|c|c|}
\hline & & & & & & & No. & Mean & S.E. & $t$ & $\mathbf{P}$ \\
\hline \multirow{7}{*}{ Total Catecholamines $(\mu \mathrm{g} / \mathrm{l})}$. & Control & . & .. & $\cdots$ & . & . & 17 & 0.76 & 0.04 & 1.88 & N.S. \\
\hline & Relaxation & $\cdots$ & $\cdots$ & .. & $\cdots$ & $\cdots$ & 17 & $0 \cdot 71$ & 0.04 & $0 \cdot 27$ & N.S. \\
\hline & Humour & $\cdots$ & $\cdots$ & $\cdots$ & . & $\cdots$ & 16 & 0.69 & 0.03 & 0.85 & N.S. \\
\hline & Violence & $\cdots$ & $\cdots$ & $\cdots$ & $\cdots$ & $\cdots$ & 16 & 0.72 & 0.03 & 1.03 & N.S. \\
\hline & Suspense & . & $\cdots$ & $\cdots$ & $\cdots$ & . & 16 & $0 \cdot 70$ & 0.02 & 0.69 & N.S. \\
\hline & Control & $\cdots$ & $\cdots$ & $\cdots$ & $\cdots$ & . & 16 & $0 \cdot 72$ & 0.04 & & \\
\hline & Control & $\cdots$ & $\cdots$ & $\cdots$ & $\cdots$ & $\cdots$ & 17 & 0.72 & 0.04 & 1.81 & N.s. \\
\hline \multirow{5}{*}{ Noradrenaline $((\mu \mathrm{g} / 1)}$. & Relaxation & $\cdots$ & $\cdots$ & $\cdots$ & $\cdots$ & $\cdots$ & 17 & 0.67 & 0.03 & 0.88 & N.S. \\
\hline & Humour & $\cdots$ & $\cdots$ & $\cdots$ & $\cdots$ & $\cdots$ & 16 & 0.64 & 0.03 & 1.49 & N.S. \\
\hline & Violence & $\cdots$ & $\cdots$ & $\cdots$ & $\cdots$ & $\cdots$ & 16 & 0.68 & 0.02 & $1 \cdot 16$ & N.S. \\
\hline & Suspense & $\cdots$ & $\cdots$ & $\cdots$ & $\cdots$ & $\cdots$ & 16 & 0.67 & 0.02 & $1 \cdot 22$ & N.S. \\
\hline & Control & $\cdots$ & $\cdots$ & $\cdots$ & $\cdots$ & $\cdots$ & 16 & 0.69 & 0.03 & & \\
\hline \multirow{6}{*}{ Adrenaline $(\mu \mathrm{g} / 1)}$. & Control & $\cdots$ & $\cdots$ & . & $\cdots$ & . & 17 & 0.05 & 0.01 & 0.57 & N.S. \\
\hline & Relaxation & $\cdots$ & $\cdots$ & .. & $\cdots$ & .. & 17 & 0.04 & 0.01 & $2 \cdot 24$ & $<0.05$ \\
\hline & Humour & $\cdots$ & . & .. & $\cdots$ & .. & 16 & 0.06 & 0.01 & 1.05 & N.S. \\
\hline & Violence & $\cdots$ & .. & .. & .. & .. & 16 & 0.04 & 0.01 & 0.48 & N.S. \\
\hline & Suspense & $\cdots$ & $\cdots$ & $\cdots$ & $\cdots$ & $\cdots$ & 16 & 0.03 & 0.01 & 0.33 & N.S. \\
\hline & Control & .. & . & $\cdots$ & $\cdots$ & .. & 16 & 0.04 & 0.01 & & \\
\hline \multirow{6}{*}{ Free Fatty Acids $(\mu \mathrm{Eq} / 1)}$. & Control & $\cdots$ & $\cdots$ & $\cdots$ & $\cdots$ & $\cdots$ & 10 & 652 & $49 \cdot 8$ & 1.30 & N.S. \\
\hline & Relaxation & $\cdots$ & - & . & $\cdots$ & - & 20 & 680 & $51 \cdot 4$ & 0.31 & N.S. \\
\hline & Humour & $\cdots$ & $\cdot$. & .. & $\cdots$ & 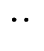 & 19 & 661 & $44 \cdot 4$ & 1.67 & N.S. \\
\hline & Violence & $\cdots$ & $\cdots$ & .. & $\cdots$ & $\cdots$ & 19 & 703 & $53 \cdot 2$ & 0.39 & N.S. \\
\hline & Suspense & $\cdots$ & $\cdots$ & .. & $\cdots$ & $\cdots$ & 19 & 697 & $53 \cdot 7$ & 0.58 & N.S. \\
\hline & Control & $\cdots$ & $\cdots$ & $\cdots$ & $\cdots$ & $\cdots$ & 19 & 713 & $58 \cdot 6$ & & \\
\hline \multirow{6}{*}{ Triglycerides $(\mathrm{mg} / 100 \mathrm{ml})$} & Control & $\cdots$ & $\cdots$ & . & $\cdots$ & $\cdots$ & 20 & 134 & $14 \cdot 7$ & 2.60 & $<0.02$ \\
\hline & Relaxation & .. & .. & .. & $\cdots$ & .. & 20 & 124 & $13 \cdot 2$ & 0.56 & N.S. \\
\hline & $\{$ Humour & $\cdots$ & $\cdots$ & .. & $\cdots$ & $\cdots$ & 19 & 123 & $13 \cdot 6$ & $2 \cdot 30$ & $<0.05$ \\
\hline & Violence & $\cdots$ & $\cdots$ & $\cdots$ & $\cdots$ & $\cdots$ & 19 & 118 & $13 \cdot 1$ & 0.50 & N.S. \\
\hline & Suspense & .. & .. & .. & $\cdots$ & $\cdots$ & 19 & 116 & $15 \cdot 1$ & $1 \cdot 19$ & N.s. \\
\hline & Control & $\cdots$ & .. & $\cdots$ & $\cdots$ & .. & 19 & 111 & $15 \cdot 9$ & & \\
\hline \multirow{6}{*}{ Cholesterol $(\mathrm{mg} / 100 \mathrm{ml})$} & Control & $\cdots$ & $\cdots$ & .. & $\cdots$ & $\cdots$ & 19 & 213 & $8 \cdot 01$ & $2 \cdot 70$ & $<0.02$ \\
\hline & Relaxation & $\cdots$ & $\cdots$ & .. & $\cdots$ & $\cdots$ & 19 & 206 & $8 \cdot 40$ & 0.75 & N.S. \\
\hline & Humour & . & .. & .. & $\cdots$ & .. & 19 & 206 & $8 \cdot 40$ & 0.55 & N.S. \\
\hline & Violence & $\cdots$ & $\cdots$ & $\cdots$ & $\cdots$ & $\cdots$ & 19 & 205 & $8 \cdot 30$ & 0.95 & N.S. \\
\hline & Suspense & $\cdots$ & $\cdots$ & .. & $\cdots$ & $\cdots$ & 19 & 207 & $8 \cdot 10$ & $1 \cdot 27$ & N.S. \\
\hline & Control & . & .. & .. & $\cdots$ & .. & 19 & 199 & $5 \cdot 25$ & & \\
\hline \multirow{6}{*}{ Glucose $(\mathrm{mg} / 100 \mathrm{ml})$} & Control & $\cdots$ & $\cdots$ & -. & $\cdots$ & $\cdot \cdot$ & 19 & $75 \cdot 8$ & 1.37 & $\mathbf{0 \cdot 2 7}$ & N.S. \\
\hline & Relaxation & $\cdots$ & $\cdots$ & . & $\cdots$ & $\cdots$ & 19 & $75 \cdot 6$ & $1 \cdot 32$ & 0.76 & N.s. \\
\hline & Humour & $\cdots$ & $\cdots$ & -. & $\cdots$ & .. & 19 & $76 \cdot 4$ & 1.84 & $4 \cdot 79$ & $<0.001$ \\
\hline & Violence & $\cdots$ & $\cdots$ & *. & $\cdots$ & $\cdots$ & 19 & $82 \cdot 5$ & $1 \cdot 30$ & $1 \cdot 78$ & N.S. \\
\hline & Suspense & $\cdots$ & $\cdots$ & .. & $\cdots$ & . & 19 & $84 \cdot 3$ & 1.54 & 1.46 & N.S. \\
\hline & Control & $\cdots$ & .. & $\cdots$ & $\cdots$ & . & 19 & $82 \cdot 3$ & 1.64 & & \\
\hline
\end{tabular}


activity suggested by the increases in plasma adrenaline, free fatty acids, and glucose more-detailed analysis of the E.C.G. tracings was carried out for evidence of augmented vagal tone. One such index is sinus arrhythmia, the slowing of the heart rate which occurs during expiration. Readings were therefore taken of the minimum and maximum heart rates in each section of the programme, the difference between the two being termed the "sinus arrhythmia," or "S.A. gap."

Analysed on this basis the E.C.G. recordings (fig. 1) showed significant decrease in minimum heart rate and increase in maximum heart rate resulting in almost trebling of the S.A. gap during the humour, violence, and suspense sections of the television programme.

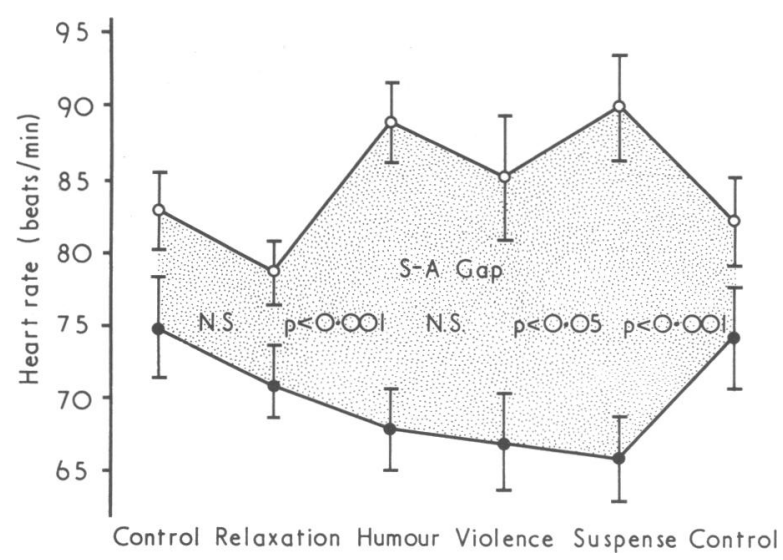

FIG. 1-Maximum ( $\bigcirc-0)$ and minimum ( -0$)$ heart rates during different periods of television programme, with $P$ values for "sinus arrhythmia gaps."

\section{Film Viewing}

The experience gained in the previous study, combined with the work of Lennart Levi (1972) on subjects viewing a variety of films, suggested that this medium might provide a more intense stimulus than television. This would be expected from the more all-embracing size of the image presented, the relative unfamiliarity of the surroundings, and the effect of being part of a larger audience. It is not unusual for the managers of cinemas showing films explicitly depicting violence to have to help people suffering vasovagal fainting attacks. In extreme cases vomiting and incontinence of urine or faeces or both may occur as additional signs of profound vagal overactivity.

Perhaps to even a greater extent than television, the cinema is under increasing criticism for relying on violence to attract audiences. In view of the cardiac responses to the violent and suspense episodes in the television programme a modified study was designed to investigate reactions to films of violence currently being shown.
METHOD

Thirty-four subjects paid a total of 46 visits to the film Clockwork Orange directed by Stanley Kubrick, and 12 subjects went to see the film Soldier Blue directed by Ralph Nelson. A $40-\mathrm{mg}$ dose of the $\beta$-blocking drug oxprenolol was administered on a single-blind basis to half of the subjects six hours and one hour before viewing the film in an attempt to separate parasympathetic from sympathetic effects. Having fasted for six hours after a light, fat-free lunch, had E.C.G. electrodes with extended leads attached, and been bled and given urine samples, the 10 or 12 subjects were taken to the cinema by taxi. The group sat in two equal rows of prebooked seats. An E.C.G. operator sat in the middle of each row and during the prefilm commercials connected the leads from each person, including his own, to a six-position switching box. The leads, lying across the subjects' laps, being covered by jumpers or jackets, were inconspicuous and caused no embarrassment or inconvenience.

By operating the six-position switch on the selector box, which was connected to the Vingmed* E.C.G. recorder, tracings could be obtained from each subject at any desired point in the film. By the simultaneous operation of a Phillips 85 "pocket memo" recorder the sound-track of the films could be used to provide a synchronous commentary, identifying recordings taken during calm and violent sections. Further blood and urine samples were obtained about 30 minutes after the end of Clockwork Orange and, by using the manager's office, three to five minutes after the particularly violent end of Soldier Blue.

\section{Results}

Urine catecholamines, calculated in $\mu \mathrm{g}$ catecholamine/creatinine, showed that the adrenaline secretion rate was almost doubled during the film as compared with the control period in all four groups (tables II to V). The rise in urinary noradrenaline level was less marked, however, and reached significance only in the unblocked group. Free fatty acids were almost doubled after the film in both unblocked groups, with much smaller increases in the blocked groups. Triglycerides decreased in all groups, but cholesterol and sugar levels remained unchanged.

The E.C.G. recordings, analysed in the same way as those taken during the television study, showed slowing to well below calm period control values in all groups during the violent sequences (figs. 2 and 3). Except for a moderate degree of slowing in the unblocked females, maximum heart rates remained almost unchanged. The increase in the S.A. gap, which occurred during the film in all groups, was more marked in the blocked subjects.

To elucidate the factors underlying the biochemical changes further hormonal estimations by standard immunoassay methods were made in the six unblocked and six blocked

* Vingmel Record System, Kimal Scientific Products Ltd., Hillingdon, Middlesex.

TABLE II-Unblocked Males. Urine Catecholamines, and Plasma Lipid and Glucose Values Before and after watching Violent Films

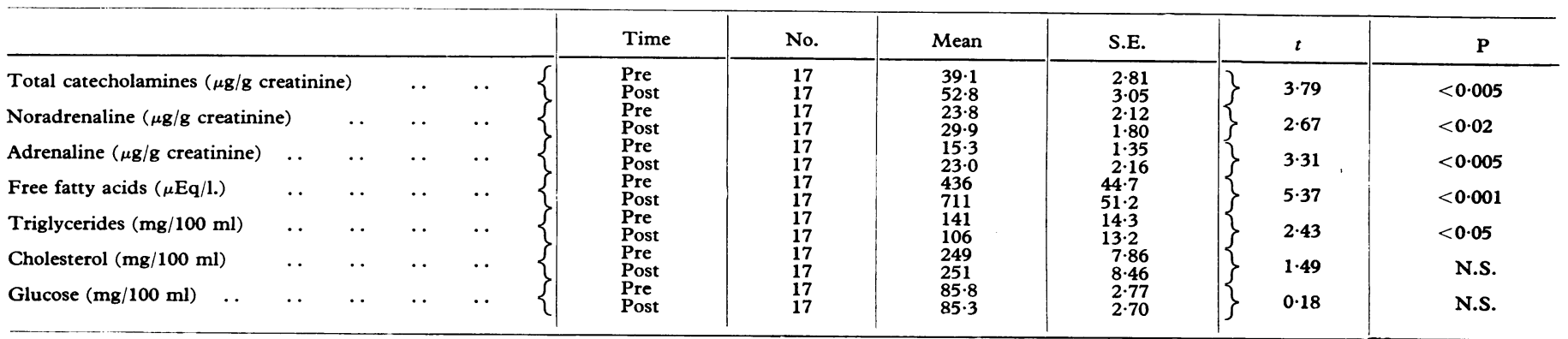


TABLE III-Blocked Males. Urine Catecholamines, and Plasma Lipid and Glucose Levels Before and after watching Violent Films

\begin{tabular}{|c|c|c|c|c|c|c|c|c|c|c|}
\hline & & & & & Time & No. & Mean & S.E. & $\boldsymbol{t}$ & $\mathbf{P}$ \\
\hline Total catecholamines $(\mu \mathrm{g} / \mathrm{g}$ & cre & ine) & . & \{ & \multirow{7}{*}{$\begin{array}{l}\text { Pre } \\
\text { Post } \\
\text { Pre } \\
\text { Post } \\
\text { Pre } \\
\text { Post } \\
\text { Pre } \\
\text { Post } \\
\text { Pre } \\
\text { Post } \\
\text { Pre } \\
\text { Post } \\
\text { Pre } \\
\text { Post }\end{array}$} & \multirow{7}{*}{$\begin{array}{l}14 \\
14 \\
14 \\
14 \\
14 \\
14 \\
14 \\
14 \\
14 \\
14 \\
14 \\
14 \\
14 \\
14\end{array}$} & \multirow{7}{*}{$\begin{array}{c}37 \cdot 1 \\
54 \cdot 2 \\
24 \cdot 7 \\
30 \cdot 7 \\
12 \cdot 4 \\
22 \cdot 8 \\
396 \\
516 \\
138 \\
97 \\
254 \\
255 \\
86 \cdot 5 \\
87 \cdot 1\end{array}$} & \multirow{7}{*}{$\begin{array}{c}3.34 \\
3.38 \\
2.39 \\
2.23 \\
1.72 \\
2.33 \\
45.1 \\
53.2 \\
17.5 \\
11.7 \\
7.24 \\
8.56 \\
2.95 \\
2.94\end{array}$} & $4 \cdot 01$ & $<0.005$ \\
\hline Noradrenaline $(\mu \mathrm{g} / \mathrm{g}$ creatinin & & .. & .. & .. & & & & & 1.94 & N.S. \\
\hline Adrenaline ( $\mu \mathrm{g} / \mathrm{g}$ creatinine) & . & $\cdots$ & .. & . $\}$ & & & & & $4 \cdot 29$ & $<0.001$ \\
\hline Free fatty acids $(\mu \mathrm{Eq} / \mathrm{l})$. & . & $\cdots$ & . & $\cdots$ & & & & & $2 \cdot 51$ & $<0.05$ \\
\hline Triglycerides $(\mathrm{mg} / 100 \mathrm{ml})$ & . & $\cdots$ & . & .. & & & & & $3 \cdot 80$ & $<0.005$ \\
\hline Cholesterol (mg/100 ml) & . & $\cdots$ & . & $\cdots \quad\{$ & & & & & $0 \cdot 26$ & N.S. \\
\hline Glucose $(\mathrm{mg} / 100 \mathrm{ml}) \quad \ldots$ & $\cdots$ & $\cdots$ & . & $\cdots\{$ & & & & & $0 \cdot 26$ & N.S. \\
\hline
\end{tabular}

TABLE IV-Unblocked Females. Urine Catecholamines, and Plasma Lipid and Glucose Values before and after watching Violent Films

\begin{tabular}{|c|c|c|c|c|c|c|c|c|c|c|}
\hline & & & & & Time & No. & Mean & S.E. & $t$ & $\mathbf{P}$ \\
\hline \multicolumn{3}{|c|}{ Total catecholamines ( $\mu \mathrm{g} / \mathrm{g}$ creatinine) } & . & \{ & \multirow{7}{*}{$\begin{array}{l}\text { Pre } \\
\text { Post } \\
\text { Pre } \\
\text { Post } \\
\text { Pre } \\
\text { Post } \\
\text { Pre } \\
\text { Post } \\
\text { Pre } \\
\text { Post } \\
\text { Pre } \\
\text { Post } \\
\text { Pre } \\
\text { Post }\end{array}$} & \multirow{7}{*}{$\begin{array}{l}13 \\
13 \\
13 \\
13 \\
13 \\
13 \\
13 \\
13 \\
13 \\
13 \\
13 \\
13 \\
13 \\
13\end{array}$} & \multirow{7}{*}{$\begin{array}{c}42.3 \\
54 \cdot 6 \\
29 \cdot 2 \\
32.5 \\
13.1 \\
22.9 \\
475 \\
853 \\
111 \\
77 \\
223 \\
226 \\
83 \cdot 4 \\
80.0\end{array}$} & \multirow{7}{*}{$\begin{array}{c}2.80 \\
3.45 \\
2.44 \\
2.60 \\
1.83 \\
1.98 \\
87 \cdot 4 \\
71.9 \\
16.9 \\
10.9 \\
6 \cdot 46 \\
8 \cdot 17 \\
3.79 \\
3.66\end{array}$} & $4 \cdot 42$ & $<0.001$ \\
\hline Noradrenaline $(\mu \mathrm{g} / \mathrm{g}$ creatinine & & . & .. & .. & & & & & $1 \cdot 21$ & N.S. \\
\hline Adrenaline ( $\mu \mathrm{g} / \mathrm{g}$ creatinine) & . & $\cdots$ & $\cdots$ & .. & & & & & $5 \cdot 44$ & $<0.001$ \\
\hline Free fatty acids $(\mu \mathrm{Eq} / \mathrm{l})$. & . & . & .. & .. & & & & & $6 \cdot 54$ & $<0.001$ \\
\hline Triglycerides $(\mathrm{mg} / 100 \mathrm{ml})$ & . & $\cdots$ & $\cdots$ & .. & & & & & $4 \cdot 13$ & $<0.005$ \\
\hline Cholesterol $(\mathrm{mg} / 100 \mathrm{ml})$ & $\cdots$ & $\cdots$ & $\cdots$ & . & & & & & $0 \cdot 85$ & N.S. \\
\hline Glucose $(\mathrm{mg} / 100 \mathrm{ml}) \quad \ldots$ & $\cdots$ & $\cdots$ & $\cdots$ & $\cdots$ & & & & & $0 \cdot 70$ & N.S. \\
\hline
\end{tabular}

TABLE v-Blocked Females. Urine Catecholamines, and Plasma Lipid and Glucose Levels before and after watching Violent Films

\begin{tabular}{|c|c|c|c|c|c|c|c|c|c|c|}
\hline & & & & & Time & No. & Mean & S.E. & $t$ & $\mathbf{P}$ \\
\hline Total catecholamines $(\mu \mathrm{g} / \mathrm{g}$ & crea & ine) & $\cdots$ & \{ & \multirow{7}{*}{$\begin{array}{l}\text { Pre } \\
\text { Post } \\
\text { Pre } \\
\text { Post } \\
\text { Pre } \\
\text { Post } \\
\text { Pre } \\
\text { Post } \\
\text { Pre } \\
\text { Post } \\
\text { Pre } \\
\text { Post } \\
\text { Pre } \\
\text { Post }\end{array}$} & \multirow{7}{*}{$\begin{array}{l}14 \\
14 \\
14 \\
14 \\
14 \\
14 \\
14 \\
14 \\
14 \\
14 \\
14 \\
14 \\
14 \\
14\end{array}$} & \multirow{7}{*}{$\begin{array}{c}38 \cdot 4 \\
52.5 \\
27 \cdot 6 \\
33 \cdot 6 \\
10 \cdot 8 \\
18.9 \\
451 \\
538 \\
109 \\
84 \\
258 \\
262 \\
88 \cdot 4 \\
89.2\end{array}$} & \multirow{7}{*}{$\begin{array}{c}2.89 \\
2.97 \\
2.25 \\
2.90 \\
1.73 \\
1.60 \\
70.4 \\
63.2 \\
16.2 \\
11.2 \\
7.91 \\
7.96 \\
2.32 \\
4.43\end{array}$} & $4 \cdot 85$ & $<0.001$ \\
\hline Noradrenaline $(\mu \mathrm{g} / \mathrm{g}$ creatinin & & .. & . & . & & & & & 1.98 & N.S. \\
\hline Adrenaline ( $\mu \mathrm{g} / \mathrm{g}$ creatinine) & $\cdots$ & . & . & . & & & & & $5 \cdot 75$ & $<0.001$ \\
\hline Free fatty acids $(\mu \mathrm{Eq} / 1)$. & . & $\cdots$ & $\cdots$ & $\cdots$ & & & & & $1 \cdot 80$ & N.S. \\
\hline Triglycerides $(\mathrm{mg} / 100 \mathrm{ml})$ & $\cdots$ & . & . & \{ & & & & & $3 \cdot 11$ & $<0.01$ \\
\hline Cholesterol (mg/100 ml) & $\cdots$ & . & $\cdots$ & . & & & & & $1 \cdot 79$ & N.S. \\
\hline Glucose $(\mathrm{mg} / 100 \mathrm{ml}) \quad \ldots$ & . & . & . & . \{ & & & & & $0 \cdot 29$ & N.S. \\
\hline
\end{tabular}

subjects attending Soldier Blue (table VI). Increases in growth hormone (HGH) and decreases in glucagon occurred in both

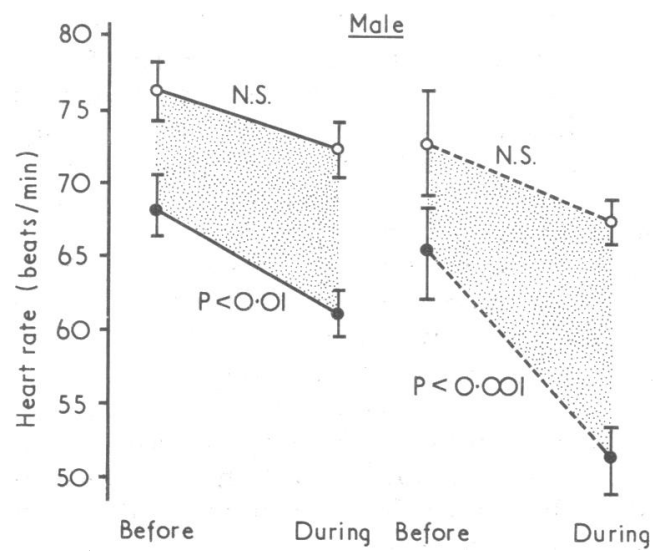

FIG. 2-Maximum ( $O$ ) and minimum (๑) heart rates in unblocked $(-)$ and blocked $(---)$ male subjects watching a violent film. groups, while no significant changes were detected in gastrin or insulin levels. 
TABLE VI-Unblocked and Blocked Film Watchers. Hormonal, Lipid, and Glucose Levels before and after watching Soldier Blue

\begin{tabular}{|c|c|c|c|c|c|c|c|c|c|c|}
\hline & & & & & Time & No. & Mean & S.E. & $t$ & $\mathbf{P}$ \\
\hline \multicolumn{4}{|c|}{ Urinary total catecholamines ( $\mu \mathrm{g} / \mathrm{g}$ creatinine) } & $\ldots$ & Pre & 12 & $43 \cdot 3$ & $2 \cdot 32$ & $2 \cdot 98$ & $<0.02$ \\
\hline \multicolumn{4}{|c|}{ Urinary noradrenaline ( $\mu \mathrm{g} / \mathrm{g}$ creatinine) } & .. & Pre & 12 & $\begin{array}{l}36 \cdot 1 \\
29 \cdot 2\end{array}$ & $\begin{array}{l}3.32 \\
2 \cdot 14\end{array}$ & $1 \cdot 20$ & N.S. \\
\hline \multicolumn{3}{|c|}{ Urinary adrenaline ( $\mu \mathrm{g} / \mathrm{g}$ creatinine) $\ldots$} & .. & .. & $\begin{array}{l}\text { Post } \\
\text { Pre }\end{array}$ & 12 & $\begin{array}{l}32 \cdot 8 \\
14 \cdot 1\end{array}$ & $\begin{array}{l}2.78 \\
1.74\end{array}$ & $3 \cdot 40$ & $<0.01$ \\
\hline \multicolumn{3}{|c|}{ Plasma immunoreactive insulin $(\mu \mathrm{U} / \mathrm{ml})$} & . & . & $\begin{array}{l}\text { Post } \\
\text { Pre } \\
\text { Post }\end{array}$ & $\begin{array}{l}12 \\
12\end{array}$ & $\begin{aligned} 22 \cdot 6 \\
2 \cdot 54\end{aligned}$ & $\begin{array}{l}2.24 \\
0.98\end{array}$ & $0 \cdot 49$ & N.S. \\
\hline Plasma glucagon (ng/ml) & .. & .. & . & . & Pre & 12 & $\begin{array}{c}<2 \cdot 00 \\
175\end{array}$ & 22.90 & $4 \cdot 40$ & $<0.005$ \\
\hline Plasma gastrin $(\mathrm{pg} / \mathrm{ml}) \ldots$ & .. & $\cdots$ & . & . & $\begin{array}{l}\text { Post } \\
\text { Pre } \\
\text { Post }\end{array}$ & $\begin{array}{r}9 \\
12 \\
8\end{array}$ & $\begin{array}{l}140 \\
54 \cdot 5 \\
49 \cdot 8\end{array}$ & $\begin{array}{r}17 \cdot 0 \\
5 \cdot 00 \\
5 \cdot 78\end{array}$ & 0.50 & N.S. \\
\hline Plasma HGH (ng/ml) $\quad$. & $\cdots$ & $\cdots$ & $\cdots$ & . & $\begin{array}{l}\text { Pre } \\
\text { Post }\end{array}$ & $\begin{array}{l}12 \\
10\end{array}$ & $\begin{array}{l}1.76 \\
6.61\end{array}$ & $\begin{array}{l}0.59 \\
2.00\end{array}$ & $2 \cdot 29$ & $<0.05$ \\
\hline Free fatty acids $(\mu \mathrm{Eq} / 1)$. & . & $\cdots$ & . & . & $\begin{array}{l}\text { Pre } \\
\text { Post }\end{array}$ & 12 & $\begin{array}{c}0.01 \\
485\end{array}$ & $\begin{array}{l}37 \cdot 0 \\
55.9\end{array}$ & $5 \cdot 18$ & $<0.001$ \\
\hline Triglycerides $(\mathrm{mg} / 100 \mathrm{ml})$ & . & $\cdots$ & $\cdots$ & $\cdots$ & $\begin{array}{l}\text { Pre } \\
\text { Post }\end{array}$ & 12 & $\begin{array}{r}103 \cdot 1 \\
78 \cdot 2\end{array}$ & $18 \cdot 7$ & 1.68 & N.S. \\
\hline Cholesterol $(\mathrm{mg} / 100 \mathrm{ml})$ & .. & $\cdots$ & . & . & $\begin{array}{l}\text { Pre } \\
\text { Post }\end{array}$ & $\begin{array}{l}12 \\
12\end{array}$ & $\begin{array}{r}255 \\
257\end{array}$ & $\begin{array}{l}11.8 \\
12.8\end{array}$ & $0 \cdot 42$ & N.S. \\
\hline Glucose $(\mathrm{mg} / 100 \mathrm{ml}) \quad \ldots$ & .. & . & . & . & $\begin{array}{l}\text { Pre } \\
\text { Post }\end{array}$ & 12 & $\begin{array}{l}81 \cdot 8 \\
76 \cdot 3\end{array}$ & $\begin{array}{r}2.83 \\
7.65\end{array}$ & $0 \cdot 77$ & N.S. \\
\hline
\end{tabular}

\section{Discussion}

The theme of Clockwork Orange is that the normal reaction to witnessing scenes of violence is a sensation of sickness amounting to an aversion. It is suggested in the film that in some people a sense of excitation predominates over this aversion, so that they either seek out or create scenes of violence to feed this appetite for excitement. The main character in the film, Alexander Delarche, is led, in his search for stimulation from violence, to the "inadvertent killing of a person." As a test case in the curtailment of prison sentences for violent criminals he undergoes aversion therapy. This consists in forcing him to watch films depicting extremes of violence and, at the same time, administering emetic drugs to re-establish the association between violence and an intense sensation of sickness. This treatment is so successful that he is released with a hypersensitivity to violence which makes him helpless in a violent society. The film ends with his abrupt desensitization by the mental and physical trauma of a suicide attempt.

A correlation is apparent between the theme of this film and the cardiological and biochemical findings in the people watching the violence it depicts. The vagotonicity of violence even in the relatively hardened medical audience examined in this study is shown by the vagal inhibition of the heart. It is supported by the changes in the levels of the hormones such as growth hormone and glucagon, which might be considered to add a neurohumoral aspect to the signs of parasympathetic activity. These appear to override the increase in sympathetic tone, indicated by the rise in urinary adrenaline excretion, as the pulse rate is decreased in subjects with and without $\beta$-blockade by oxprenolol. The rise in free fatty acids and fall in triglycerides could also be explained by the action of human growth hormone in activating lipoprotein lipase, whereas the sympathetic effects are abolished by $\beta$-blockade (Taggart and Carruthers, 1972; Carruthers et al., 1973). The complex interactions of these hormones on each other and on all aspects of lipid and carbohydrate metabolism, together with the lack of control data from samples taken after viewing tranquil films, make further studies necessary before any definite conclusions can be reached.

Most studies of the physiological and biochemical responses to film watching have concentrated on the evidence of increased sympathetic activity. This has consisted of the increased urinary excretion of noradrenaline and adrenaline while viewing almost any type of film, whether humorous, aggressive, or pornographic (Levi, 1972). Only bland, natural scenery films decreased the secretion of both amines. In this study the fact that the vagal effects on the heart were least during the non-violent sections of the programme indicates that it was not just the warmth and comfort of the environment which brought about these changes. Neither did it appear to be an effect of the music, as control sessions spent listening to the Warner Brothers' record of the sound track of the film produced no indications of increased vagal tone. Lazarus et al. (1971) showed peaks of heart rate and skin conductance just before and for a minute or two after mutilating accidents or operations depicted on film. Perhaps more interesting are the troughs following these brief peaks, which appear in spite of the use of the sophisticated technique of scoring heart rate by a method called "mean cyclic maxima, smoothed by moving averages of the order three" (Lazarus, 1967).

Slowing of the heart rate, even in the presence of increased sympathetic activity, was mentioned by Obrist (1963) as a response to sensory stimuli involving continuous environmental input, though no physiological mechanism was suggested. Similarly, Levi (1971) described a study in which subjects with dental phobia were shown films of dental treatment. This produced a pronounced bradycardia, again in spite of increased adrenaline secretion. In one of his subjects this vagal reaction was sufficiently pronounced to cause a 10-second period of asystole and syncope. This is in marked contrast to the tachycardia of up to 150 beats/min induced even in subjects with dental phobia by the dental operations themselves. It illustrates an important difference in responses to observed and experienced traumatic events (Edmondsun et al., 1972).

Psychological immunization by films was put forward by Henderson et al. (1972) for "systematic automated desensitization" of anxiety-prone groups. They also quoted the work of Folkins et al. (1968) and Davidson and Hiebert (1971) that repeated exposure to films depicting mutilating accidents or operations could lessen the subsequent subjective and physiological responses to similar stress. Both these groups of workers emphasized that the effectiveness of such treatments to reduce stress lies not in the initial exposure to the stressor but in repeated exposure or, in psychological terms, "cognitive rehearsal."

Much research already carried out (Halloran, 1967; Hamberg, 1971) has consistently shown that violent behaviour can be learnt from films and television. Like most teaching it is especially effective at an early age when related to real-life situations, carried out by people with whom the subject can identify, made interesting and exciting, and, above all, when it is rewarded and encouraged by peer groups. The stimulating influence of crowds and martial music-cthat divine dynamite"in rousing the aggressive emotions and counteracting vagal inhibitions was well known to military leaders before Cannon described it in 1929. Kubrick reinforces this message by using the music of Beethoven and Rossini to make the violence of Clockwork Orange acceptable. Thus to increase the audience for violence the vehicle for it is supercharged with the excitement generated by sexual themes and powerful music and given a hard gloss of professionalism, enabling the most sordid events to be presented in a brilliant, glittering "ultraviolent" light (Carruthers, 1973). 
The present study suggests that these objective methods, especially with the addition of $\beta$-blockade, could be used to measure the rate of desensitization produced by the portrayal of violence on television and in films. It is, perhaps, optimistic to expect that this vagally mediated aversion to violence can be allowed to decrease in the population without socially harmful effects becoming apparent. Being "sick to the heart" with violence may be one of the most effective and necessary forces in restraining man's innate tendency to aggression.

The studies on television watchers were made possible by the kind help of Dr. Effron Gwynne-Jones, of the Further Education Department of the B.B.C. CIBA Company provided financial assistance and some of the volunteers for the studies on film viewing. Our thanks are also due to the Medical Research Council for providing the AutoAnalyzer on which the analyses were performed, and to Professor Norman Ashton for laboratory facilities while M.C. was at the Institute of Ophthalmology. Miss Eileen Willmott provided valuable technical help and Mr. Brian Augier analysed the results. We are grateful to members of the Audio-Visual Department of Moorfields Eye Hospital for use of their television replay facilities. Mr. David Gibbons provided skilled help with the E.C.G. techniques and constructed the switching boxes for the E.C.G. recorders.

Reprints may be obtained from Dr. M. Carruthers, Department of Chemical Pathology (Research), St. Mary's Hospital Medical School, London W2 1 PG.

\section{References}

B.B.C. Audience Research Department (1972). Violence on Television: Programme Content and Viewer Perception. London, British Broadcasting Corporation.

British Medical fournal, 1973, 2, 565.

Cannon, W. B. (1929). Bodily Changes in Pain, Hunger, Fear and Rage, 2nd edn. New York, Appleton.

Carruthers, M. E. (1973). The Western Way of Death. London, DavisPoynter. In press.

Carruthers, M. E., Taggart, P., and Somerville, W. (1973). In New Perspectives in $\beta$-Blockade, ed. D. M. Burley, J. H. Frier, R. K. Rondel, spectives in $\beta$-Blockade, ed. D. M. Burley, J. H. Frier,
and S. H. Taylor, p. 307. Horsham, Ciba Laboratories.

Davidson, P. O., and Hiebert, S. F. (1971). Fournal of Abnormal Psychology, 78, 154.

Edmondson, H. D., Roscoe, B., and Vickers, M. D. (1972). British Medical fournal, 4,7 .

Folkins, C. H., Lawson, K. D., Opton, E. M., and Lazarus, R. S. (1968). fournal of Abnormal Psychology, 73, 100.

Halloran, J. D. (1967). Attitude Formation and Change. Leicester University Press.

Hamberg, D. A. (1971). Sir Geoffrey Vickers Lecture. London, Mental Health Research Fund. Quoted by Harrington (1972).

Harrington, J. A. (1972). British Medical fournal 1, 228.

Henderson, A. S., Montgomery, I. M., and Williams, C. L. (1972). Lancet, 1,1111 .

Lancet, $1970,1,460$

Lazcet, 1970, 1, 460. In Emotional Stress, ed. L. Levi, p. 169. Basel, Karger

Lazarus, R. S. (1967). In Emotional Stress, ed. L. Levi, p. 169. Basel, Karger. Disease, ed. L. Levi, p. 190. London, Oxford University Press.

Levi, L. (editor) (1971). In Society, Stress and Disease, p. 466. London, Oxford University Press.

Levi, L. (1972). Acta Medica Scandinavica, Suppl. No. 528.

Obrist, P. A. (1963). Psychosomatic Medicine, 25, 450.

Rollason, W. N. (1964). Electrocardiography for the Anaesthetist. Oxford, Blackweil

Taggart, P., and Carruthers, M. E. (1971). Lancet, 1, 363.

Taggart, P., and Carruthers, M. E. (1972). Lancet, 2, 256.

\title{
Treatment of Muscle Cramps during Maintenance Haemodialysis
}

\author{
G. R. D. CATTO, F. W. SMITH, M. MACLEOD
}

British Medical fournal, 1973, 3, 389-390

\section{Summary}

The effect of a slowly released oral preparation of sodium chloride (Slow Sodium) on the frequency and severity of muscle cramps, on blood pressure, and on body weight was compared with that of placebo in a double-blind cross-over trial in 19 patients on maintenance haemodialysis for endstage renal failure. A significant reduction in both the frequency and severity of cramps was found while the patients were receiving the sodium chloride preparation and no significant alteration in blood pressure or body weight was detected.

\section{Introduction}

Muscle cramps occur frequently in patients on maintenance haemodialysis (Eady, 1971; Strauch et al., 1971). The aetio$\operatorname{logy}$ of the condition is not definitely established. Acute oxygen deficiency in metabolically active muscles is considered to be one factor (Chillar and Desforges, 1972). There

University Department of Medicine, Aberdeen AB9 2ZD

G. R. D. CATTO, M.B., M.R.C.P., Research Fellow

M. MACLEOD, M.D., F.R.C.P., Reader in Medicine

Medical Renal Unit, Aberdeen Royal Infirmary, Aberdeen AB9 2ZD F. W. SMITH, M.B., CH.B., Registrar is evidence that a reduction in circulating plasma volume with cellular overhydration is another important aetiological cause (Stewart et al., 1972). It has been noted both in this unit and elsewhere (Gotloib and Servadio, 1972) that intravenous injection of $10-20 \mathrm{ml} 22.5 \%$ sodium chloride solution rapidly relieves muscle cramps. It was decided, therefore, to assess the value of a slowly released oral preparation of sodium chloride (Slow Sodium) as a prophylactic measure. The effect of Slow Sodium on the frequency and intensity of muscle cramps, on blood pressure, and on body weight was compared with that of placebo in a double-blind cross-over trial in patients on regular haemodialysis.

\section{Patients and Methods}

Nineteen patients on maintenance haemodialysis (12 men, 7 women) were admitted to the trial. One patient taking the placebo died from acute bacterial endocarditis and another was withdrawn from the trial while receiving the sodium chloride preparation. Tablets of Slow Sodium contain 600 mg sodium chloride (equivalent to $10 \mathrm{mEq} \mathrm{Na}{ }^{+}$and $\mathrm{Cl}-$ ) prepared in a wax sponge formulation.

Patients were allocated at random to two groups. Patients in the first group were given 14 tablets of Slow Sodium (140 $\mathrm{mEq}$ sodium) during each dialysis for two months followed by 14 placebo tablets during each dialysis for a further two months. The second group received the preparations in the reverse order. Tablets given at each dialysis were administered as follows: 6 tablets half to one hour before starting dialysis, 4 tablets four hours after the start of dialysis, and 4 tablets six hours after the start of dialysis. 